Tạp chí Các Khoa học về Trái Đất, 38 (1), 118-130

\begin{tabular}{c} 
Viện Hàn lâm Khoa học và Công nghệ Việt Nam \\
Tạp chí Các Khoa học về Trái Đất \\
WAST) \\
Website: http://www.vjs.ac.vn/index.php/jse \\
\hline
\end{tabular}

\title{
Diễn biến xói lở-bồi tụ ven biển Hải Hậu (tỉnh Nam Định) và vùng lân cận trong hơn 100 năm qua trên cơ sở phân tích tài liệu bản đồ địa hình và tư liệu viễn thám đa thời gian
}

\author{
Phạm Quang Sơn*, Nguyễn Đức Anh \\ Viện Địa chất, Viện Hàn lâm Khoa học và Công nghệ Việt Nam
}

Chấp nhận đăng: 12 - 2 - 2016

\begin{abstract}
Evolution of the coastal erosion and accretion in the Hai Hau district (Nam Dinh province) and

neighboring region over the last 100 years based ontopographic maps and multi-temporal remote sensing data analysis

Coastal zone of Nam Dinh province is a terrain slow (elevation from $0.0 \mathrm{~m}$ to $1.8 \mathrm{~m}$ ), located between large estuaries of the Red river system such as Ba Lat, Lach Giang and Day. This area, beside the large estuaries having fast alluvial accretion, the shoreline section of $29 \mathrm{~km}$ long in the Hai Hau district is being seriously eroded and and deformed caused by various reasons. This paper presents achievements in evaluation of shoreline evolutions in the Hai Hau district and neighbouring areas based on the analysis of topographic maps in combinantion with multi-temporal Remote Sensing data and and other data sources in order to illustrate the overall erosion and deforming situation in the Hai Hau coastal region. This process has been going for more than 100 years under the influence of natural factors and human activities.
\end{abstract}

(C2016 Vietnam Academy of Science and Technology

\section{Mở đầu}

Vùng ven biển đồng bằng sông Hồng (ĐBSH), trong đó có ven biển tỉnh Nam Định, đã có những biến đổi lớn do hiện tượng xói lở - bồi tụ trong quá trình phát triển châu thổ ở Bắc Bộ. Biến đổi vùng ven biển do tác động của nhiều nhân tố tự nhiên và hoạt động của con người, trong đó có ảnh hưởng do vận hành khai thác các nhà máy thủy điện ở thượng lưu sông Hồng, hoạt động khai thác và chỉnh trị ở vùng ven biển, tác động của bão, áp thấp nhiệt đới (ATNĐ) và lũ lớn (Lương Tuấn Anh (chủ biên, 2013; Nguyễn Văn Cư và nnk, 1990; Gérard Maire and Pham Quang Son, 1993; Vũ Thị

*Tác giả liên hệ, Email: quangsonpham2010@gmail.com
Thu Lan (chủ biên), 2015; Phạm Quang Sơn, 2004). Những khu vực phát triển bồi tụ mạnh nhất ở ven biển ĐBSH là các cửa sông thuộc hệ thống sông Hồng - sông Thái Bình. Những vùng bờ biển xói lở nằm xen kẽ trên các đoạn bờ khác nhau, điển hình là hiện tượng xói lở bờ biển huyện Hải Hậu (tỉnh Nam Định) đã diễn ra liên tục trong hàng chục năm qua, gây khó khăn rất lớn cho việc bảo vệ an toàn hệ thống đê biển, các công trình kỹ thuật ven biển và các khu dân cư trong mùa mưa bão.

Trên cơ sở phân tích các tài liệu bản đồ địa hình nhiều thời kỳ, các tư liệu ảnh vệ tinh đa thời gian phân giải cao và các tài liệu nghiên cứu khác có liên quan, trong khuôn khổ bài báo này chúng tôi muốn đề cập tới tình trạng xói lở - bồi tụ, quy 
P.Q. Sơn và N.Đ. Anh/Tạp chí Các Khoa học về Trái Đất, Tập 38 (2016)

mô biến động ở vùng ven biển huyện Hải Hậu (tỉnh Nam Định) và vùng kề cận, đã diễn ra phức tạp trong thời gian hơn 100 năm qua.

\section{Nguồn tài liệu sử dụng trong nghiên cứu}

\subsection{Vùng nghiên cứu}

Vùng nghiên cứu chính (hình 1) thuộc ven biển huyện Hải Hậu (tỉnh Nam Định) và khu vực lân cận thuộc địa phận các huyện Nghĩa Hưng và Giao Thủy. Khu vực này có các hoạt động khai thác và chỉnh trị đã diễn ra mạnh mẽ ở ven biển; với những hình thức khai thác chính là quai đê lấn biển, nạo vét luồng lạch giao thông thủy, xây dựng các tuyến đê ngăn lũ, ngăn nước mặn, xây dựng các hệ thống kè hộ bờ - giảm sóng - ngăn dòng bùn cát và dòng chảy ven bờ,...

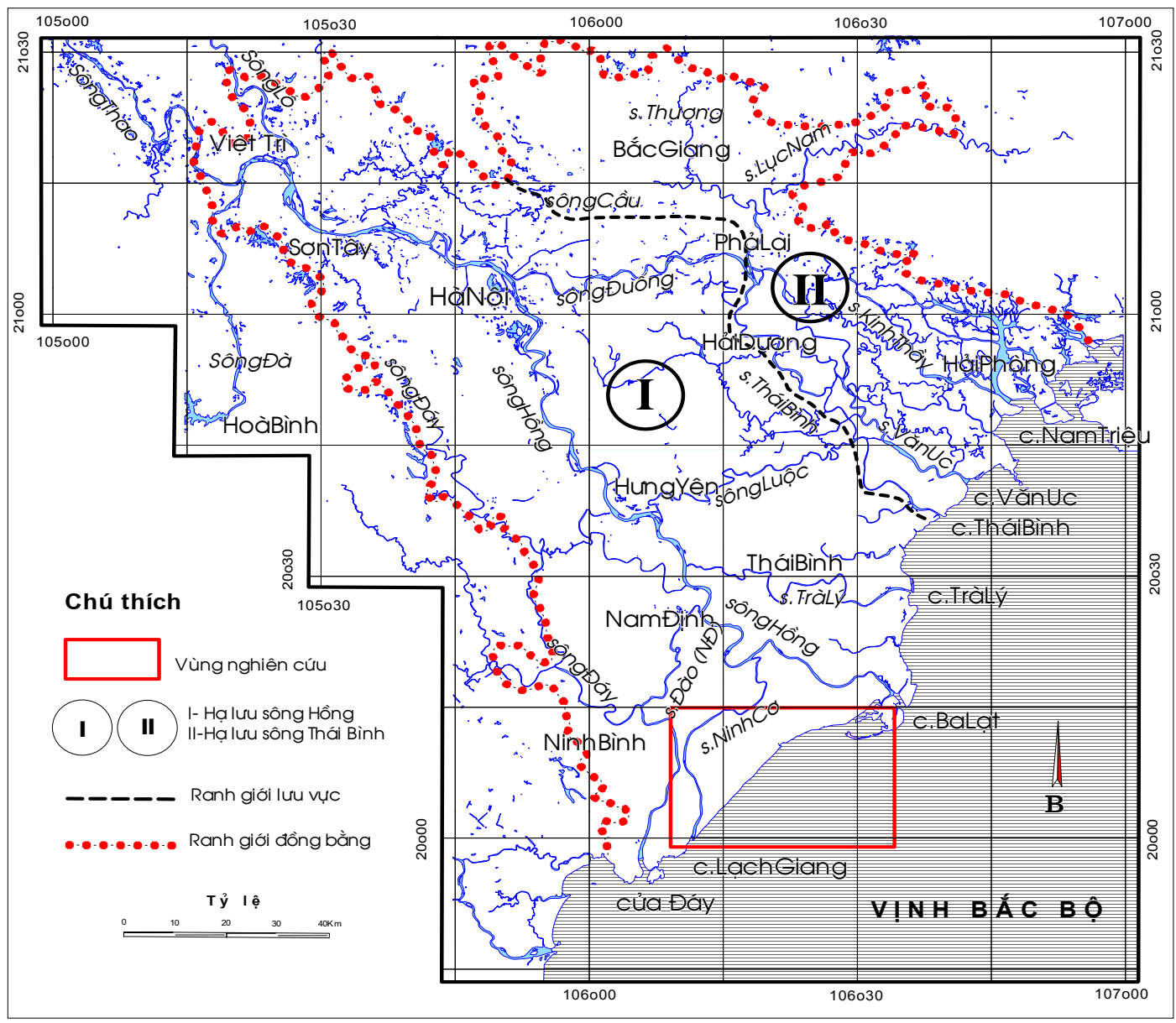

Hình 1. Vị trí vùng nghiên cứu ven biển Hải Hậu - tỉnh Nam Định

\subsection{Tài liệu sử dụng}

Trong nghiên cứu, chúng tôi đã sử dụng các nguồn tài liệu khác nhau: kết quả các chuyến khảo sát thực địa ven biển Nam Định, tư liệu ảnh vệ tinh chụp nhiều thời kỳ, bản đồ địa hình và các tư liệu khác có liên quan:
- Tài liệu nghiên cứu thủy văn, hải văn (dòng chảy, dòng bùn cát, dao động mực nước, sóng gió, thủy triều,...) trên hệ thống sông Hồng;

- Các ảnh vệ tinh Landsat, Spot, Radarsat, Sentinel chụp trong các năm: 1975, 1989, 1991, 1995, 1999, 2001, 2003, 2005, 2008, 2010, 2013, 2014, 2015 (hình 2); 
Tạp chí Các Khoa học về Trái Đất, 38 (1), 118-130

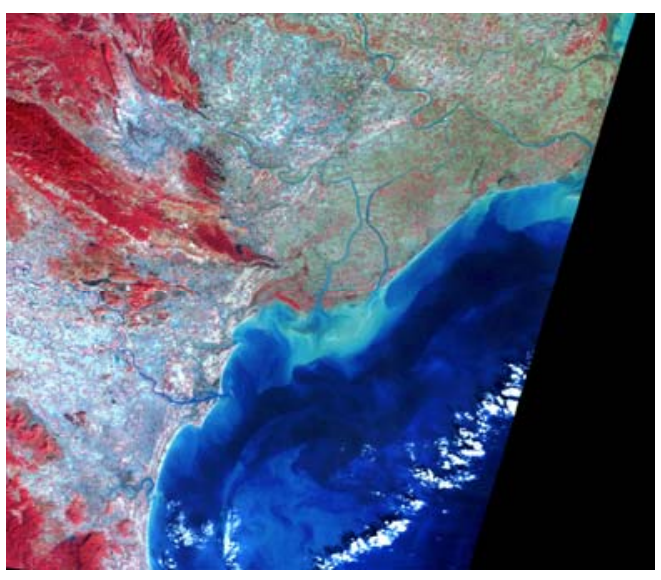

(a) $1975(01 / 11 / 1975)$

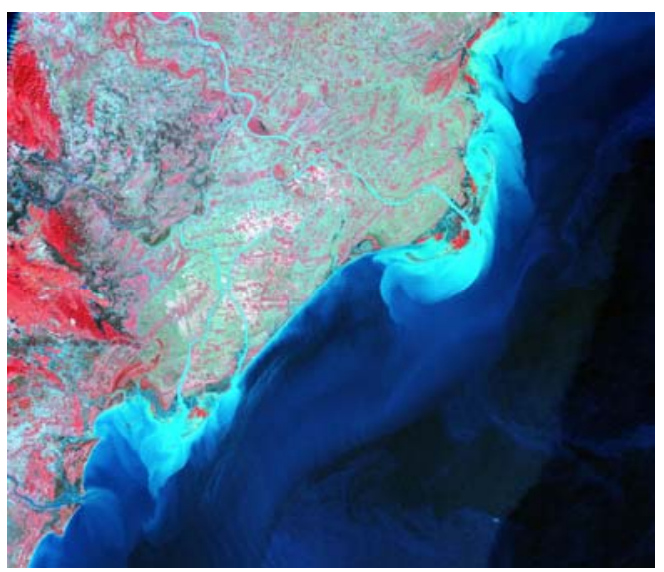

(c) $2001(16 / 11 / 2001)$

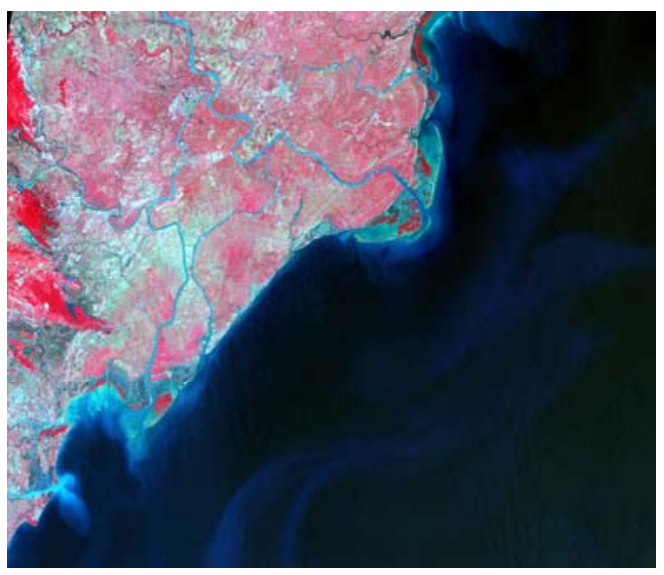

(e) $2013(22 / 09 / 2013)$

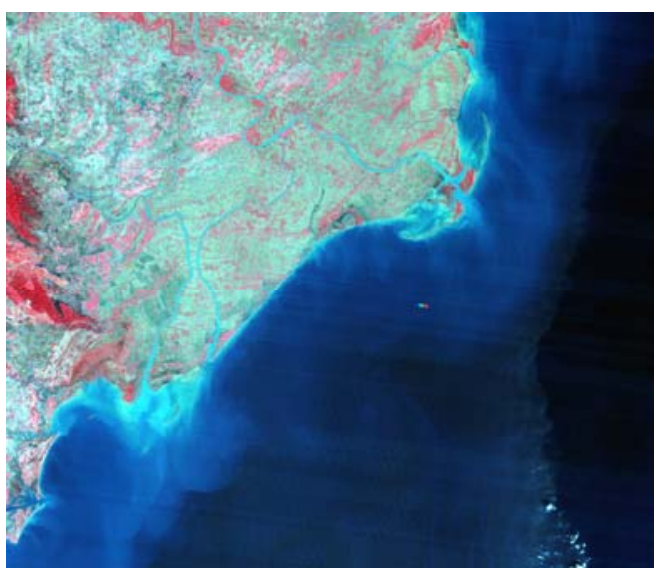

(b) $1989(23 / 11 / 1989)$



(d) $2008(21 / 02 / 2008)$

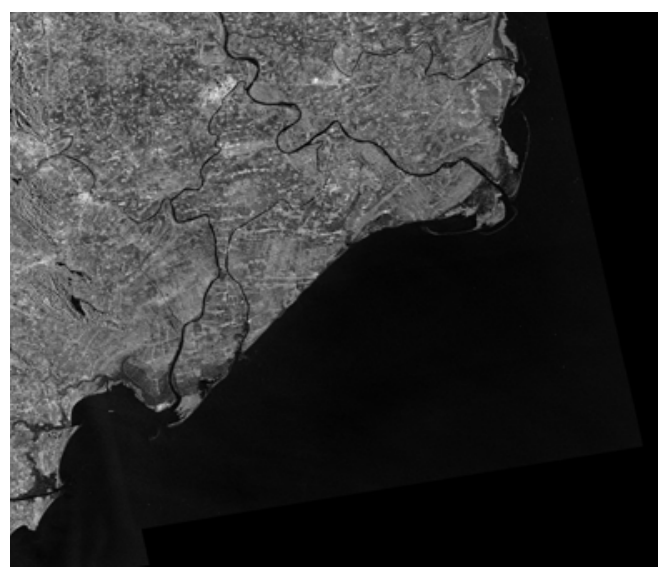

(f) $2015(18 / 01 / 2015)$

Hình 2. Một số loại ảnh vệ tinh sử dụng trong nghiên cứu ven biển Hải Hậu (Nam Định); (a)-ảnh MSS; b-ảnh TM; (c, d) ảnh ETM; (e)-ảnh OLI; (f)-ảnh SAR 
P.Q. Sơn và N.Đ. Anh/Tạp chí Các Khoa học về Trái Đất, Tập 38 (2016)

- Các bản đồ địa hình xuất bản từ năm 1954 trở về trước $(1912,1927,1935,1954)$ tỷ lệ $1: 100.000$ và từ năm 1965 đến nay $(1965,1978,1990,2010)$ tỷ lệ $1: 50.000$ và $1: 25.000$;

- Tài liệu khảo sát thực địa tại vùng ven biển và các cửa sông ở Nam Định, Ninh Bình trong khuôn khổ một số đề tài nghiên cứu (Nguyễn Văn Cư và nnk, 1990; Nguyễn Địch Dỹ và nnk, 2009; Phạm Quang Sơn, 2004; Phạm Quang Sơn và nnk, 2007, 2011).

Dữ liệu không gian (các ảnh vệ tinh, bản đồ địa hình, số liệu độ cao) được xử lý trên các hệ thống phần mềm chuyên dụng về viễn thám và GIS; như PCI, ENVI, ArcGis, ArcView, Mapinfo. Phương pháp xử lý thông tin không gian và chiết xuât đường bờ đã được các tác giả công bố trên các công trình khác nhau (Gérard Maire and Pham Quang Son, 1993; Giles Foody \& Paul Curran, 1994; Michel Girard and Autre, 1989; Phạm Quang Sơn, 2004; Phạm Quang Sơn và nnk, 2007).

\section{Khái quát điều kiện tự nhiên, các hoạt động} khai thác - chỉnh trị ở vùng nghiên cứu

\section{1. Địa hình ven biển}

Bề mặt địa hình tương đối bằng phẳng, hơi nghiêng về phía biển, độ dốc nhỏ, dao động $0,04 \div 0,05 \mathrm{~m} / \mathrm{km}$. Độ cao trung bình dao động $0,0 \div 1,8 \mathrm{~m}$. Địa hình nhân tạo tiêu biểu ở đây là hệ thống đê ngăn lũ ven sông và đê biển. Hệ thống đê và các trục giao thông đã chia cắt ven biển Hải Hậu ra những ô đất thấp khác nhau.

\subsection{Khí hậu}

Chịu sự ảnh hưởng của hai hệ thống gió mùa Đông Bắc và gió mùa Tây Nam có tính chất đối ngược nhau chi phối.

- Gió ven biển: Mùa đông thịnh hành các hướng gió $\mathrm{B}(22,4 \%), \mathrm{ÐB}(17,3 \%)$ và $\mathrm{Ð}(37,1 \%)$. Mùa hè thịnh hành các hướng gió $\mathrm{N}(25,2 \%)$ và

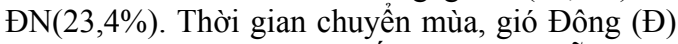
là hướng gió chính. Khi xuất hiện các nhiễu động thời tiết đặc biệt như dông, lốc, bão,... tốc độ gió có thể tới $45 \mathrm{~m} / \mathrm{s}$.

- Mưa: Lượng mưa hàng năm dao động $1540 \div 1750 \mathrm{~mm}$. Mùa mưa bắt đầu từ cuối tháng IV và kết thúc vào tháng $X$, chiếm $82 \div 90 \%$ lượng mưa cả năm. Mưa lớn tập trung vào các tháng VIIVIII. Lượng mưa ngày lớn nhất đạt tới 300mm.
Mưa lớn có thể gây ra ngập úng cục bộ ở ven biển Hải Hậu.

- Bão, áp thấp nhiệt đới: Tính chung, trong hơn 100 năm qua khu vực này chịu tác động của khoảng $28 \%$ số trận bão và áp thấp ở Việt Nam; trung bình hàng năm có $1-2$ trận tác động trực tiếp và 2-3 trận khác tác động gián tiếp. Nhưng trong khoảng 20 năm trở lại đây, số trận bão và áp thấp đổ bộ vào khu vực này có tần suất giảm đi, nhưng cường độ lại mạnh hơn.

\subsection{Sông ngòi}

Vùng nghiên cứu nằm kẹp giữa hai cửa sông lớn là cửa $\mathrm{Ba}$ Lạt (sông Hồng) và cửa Lạch Giang (sông Ninh Cơ). Hai nhánh sông lớn này chuyển tải khoảng $38-43 \%$ tổng lượng nước và bùn cát của sông Hồng. Ngoài ra, còn có các nhánh sông nhỏ khác, đóng vai trò như những hệ thống thủy văn tự nhiên, cung cấp nước tưới cho nông nghiệp và tiêu thoát nước vào mùa mưa. Trong số này, đáng kể nhất là sông Sò, là sông tự nhiên đã được cải tạo, đưa nước sông Hồng ra cửa Hà Lạn. Hiện nay cửa Hà Lạn (sông Sò) đã bị bồi lấp mạnh.

\section{4. Đặc điểm địa chất - địa mạo}

Vùng ven biển Nam Định nằm ở phần Đông Nam châu thổ, thuộc trũng Sông Hồng, có các đứt gãy kiến tạo lớn chi phối, như các đứt gãy sông Hồng, sông Chảy, sông Lô,... Quá trình sụt lún ở châu thổ được bù đắp bởi lượng phù sa dồi dào. Tốc độ sụt lún trong Đệ tứ được xác định là $0,12 \mathrm{~mm} /$ năm ở vùng đông bắc và $0,06 \mathrm{~mm} /$ năm ở rìa tây nam (Trần Nghi và nnk, 2000). Trong đới cấu trúc trũng sụt lún, các móng đá gốc thể hiện rất ít trên bề mặt đồng bằng (dạng đồi núi sót), hầu hết bị chôn vùi dưới lớp phủ của các lớp trầm tích từ Neogen đến Đệ tứ. Trầm tích Holocen rất đa dạng về thành phần và nguồn gốc; bao gồm cát, bột, bột sét, bùn sét,... (Doãn Đình Lâm, 2002; Vũ̃ Văn Phái, Nguyễn Hoàn, Nguyễn Hiệu, 2002; Trần Nghi, Chu Văn Ngợi và nnk, 2000; Trần Đức Thạnh, 2008). Trong giai đoạn phát triển châu thổ hiện đại, khu vực ven biển chịu ảnh hưởng rất lớn bởi các hoạt động của con người, trong đó có việc đắp đê ngăn lũ đã làm mất mối trao đổi phù sa giữa sông và đồng bằng, làm cho bề mặt ven biển vốn chưa được bồi đầy lại có thêm nhiều ô trũng.

\subsection{Hoạt động khai thác và chỉnh trị ven biển}

Đắp đê và khai hoang lấn biển là hoạt động của con người có ảnh hưởng nhiều nhất ở ven biển 
Tạp chí Các Khoa học về Trái Đất, 38 (1), 118-130

Nam Định, được ghi nhận từ các triều đại phong kiến. Đi đôi với khai hoang lấn biển là việc nạo vét luồng lạch sông ngòi, xây đập chặn dòng chảy, xây dựng các vùng kinh tế mới ven biển. Việc nạo vét các luồng vận tải thủy ở đồng bằng và các cửa sông đã góp phần phân phối lại dòng chảy và dòng phù sa giữa các sông lớn ở châu thổ. Tuyến đê biển ở Hải Hậu và lân cận được bồi đắp, tôn tạo mạnh sau khi Miền Bắc được giải phóng (1954); tiếp đó là phát triển khai hoang lấn biển đã diễn ra rất mạnh vào những năm 1960 ở khu vực này, như tại Giao Long - Bạch Long (h. Giao Thủy), Rạng Đông (h. Nghĩa Hưng), Bình Minh (h. Kim Sơn). Bên cạnh khu vực các cửa sông lớn được bồi tụ mạnh thì nhiều vùng ven biển khác ở Nam Định lại diễn ra xói lở mạnh, điển hình là ven biển Hải Hậu. Do tình trạng xói lở bờ biển diễn ra rất mạnh ở Hải Hậu, nên tuyến đê biển ở đây liên tục được bồi đắp, củng cố và chỉnh trị bằng những công trình kỹ thuật như kè hộ mái đê, tường chống sóng leo, kè chặn dòng ven bờ, kè giảm sóng (Nguyễn Văn Cư, Phạm Quang Sơn và nnk, 1990; Nguyễn
Văn Hạnh, 2015; Vũ Thị Thu Lan (chủ biên), 2015; Phạm Quang Sơn và nnk, 2007; Trần Đức Thạnh, 2008).

\section{Diễn biến xói lở-bồi tụ, quy mô không gian biến động ven biển Hải Hậu và vùng lân cận trong hơn 100 năm qua}

Qua phân tích tư liệu bản đồ địa hình (xuất bản từ năm 1912 đến 2010) và ảnh vệ tinh (chụp từ năm 1975 đến 2015) ghi nhận hiện trạng vùng ven biển Hải Hậu trong thời gian khác nhau. Qua xử lý thông tin, cho thấy bức tranh tổng thể về diễn biến đường bờ biển và tình hình xói lở-bồi tụ ở ven biển Hải Hậu và lân cận diễn ra rất đa dạng. Với sự trợ giúp của các phần mềm xử lý ảnh viễn thám và GIS, chúng tôi đã xây dựng được các bản đồ về phân bố vị trí đường bờ ở các thời gian khác nhau; bản đồ phân bố không gian biến động vùng ven bờ trong khoảng 100 năm qua (1912-2014) (hình 3) và xây dựng được loạt bản đồ về diễn biến xói lở bồi tụ trong các chu kỳ ngắn (4-17 năm).



Hình 3. Diễn biến vị trí đường bờ ven biển Hải Hậu và lân cận, từ 1912 đến 2014 


\section{P.Q. Sơn và N.Đ. Anh/Tạp chí Các Khoa học về Trái Đất, Tập 38 (2016)}

\subsection{Diễn biến xói lở - bồi tụ bờ biển khu vụcc nghiên cứu}

Phân tích các bản đồ kết quả, cho thấy ven biển Hải Hậu và lân cận trong các giai đoạn từ 1912 đến 2014 có diễn biến như sau:

\subsubsection{Giai đoạn nhũng năm 1912-1927-1935}

Trong các năm từ 1912 đến 1935 (hình 4a) ở ven biển Nam Định phải hứng chịu liên tiếp các trận bão và áp thấp nhiệt đới. Bờ biển các huyện Hải Hậu và Giao Thủy biến động mạnh. Vùng bồi tụ mạnh nhất nằm kề các cửa sông lớn; cụ thể là khu vực bờ biển các xã từ Giao Châu đến Giao Lạc thuộc Giao Thủy đã hình thành các bãi bồi lớn, có chiều rộng lớn nhất là $1.600 \mathrm{~m}$ và trung bình là $750 \mathrm{~m}$; vùng bồi tụ lớn thứ hai nằm kề cửa Lạch Giang thuộc địa phận thị trấn Thịnh Long ngày nay, có chiều dài $5,3 \mathrm{~km}$ và rộng trung bình $280 \mathrm{~m}$. Bên cạnh các vùng bồi lớn nằm kề các cửa sông thì vùng xói lở mạnh kéo dài gần $10 \mathrm{~km}$ từ vị trí thị trấn Quất Lâm (Giao Thủy) đến khu vực xã Hải Hoà (Hải Hậu). Chiều rộng vùng bờ xói lở lớn nhất là $1.200 \mathrm{~m}$ và trung bình rộng $130 \mathrm{~m}$; tương đương tốc độ xói trung bình $5,6 \mathrm{~m} /$ năm và lớn nhất tới $52 \mathrm{~m} / \mathrm{năm}$. Trong giai đoạn này bờ biển Hải Hậu - Giao Thủy phát triển thiên về trạng thái xói lở mạnh.

\subsubsection{Giai đoạn năm 1935-1953}

Trong các năm từ 1935 đến 1953 (hình 4b) ở ven biển Hải Hậu - Giao Thủy tiếp tục biến động mạnh bởi quá trình bồi tụ và xói lở bờ. Vùng bồi tụ diễn ra với cường độ mạnh ở khu vực các xã Giao Tiến - Bạch Long ngày nay, bởi quá trình bồi tụ lấp vịnh nước nông ven bờ thuộc địa phận $\mathrm{h}$. Giao Thủy. Khu vực bồi mạnh còn diễn ra ở cửa sông Sò (cửa Hà Lạn) và ven cửa Lạch Giang (ven biển thị trấn Thịnh Long ngày nay). Ngược lại, quá trình xói lở bờ diễn ra xen kẽ trên các đoạn bờ ngắn, có chiều dài từ $1,4 \mathrm{~km}$ đến $4,5 \mathrm{~km}$. Vùng xói lở mạnh nhất diễn ra trên địa phận h. Giao Thủy (thuộc bờ biển các xã Giao Long - Giao Hải) với chiều dài gần $7 \mathrm{~km}$; vùng bờ xói lở rộng nhất là $300 \mathrm{~m}$ và rộng trung bình là $120 \mathrm{~m}$, tương đương tốc độ xói lở trung bình $6,6 \mathrm{~m} / \mathrm{năm}$, lớn nhất $16,5 \mathrm{~m} /$ năm. Nhìn chung, trong giai đoạn này bờ biển Hải Hậu - Giao Thủy có quá trình xói lở và bồi tụ diễn ra tương đối cân bằng.

\subsubsection{Giai đoạn năm 1953-1965}

Trong các năm từ 1953-1965 (hình 4c) ở ven biển Hải Hậu - Giao Thủy có quá trình phát triển diễn ra khá mạnh, thiên về trạng thái xói lở. Vùng bờ xói lở chính thuộc địa phận Giao Thủy có chiều dài từ 7,6km; đoạn bờ xói lở thuộc địa phận Hải Hậu có chiều dài tới $16,2 \mathrm{~km}$. Tương tự như giai đoạn trước, bão và áp thấp nhiệt đới hoạt động mạnh và có tác động lớn tới khu vực ven biển này. Vùng bờ xói lở có chiều rộng lớn nhất tới $800 \mathrm{~m}$ và trung bình là $130 \mathrm{~m}$; tương đương tốc độ xói lở trung bình $5,2 \mathrm{~m} /$ năm và lớn nhất $67 \mathrm{~m} /$ năm. Các vùng bồi tụ chính diễn ra ở khu vực nước nông thuộc các xã Giao Phong - Bạch Long (h. Giao Thủy) và ven biển cửa Lạch Giang (TT. Thịnh Long) và khu vực xã Hải Hoà (h. Hải Hậu).

\subsubsection{Giai đoạn năm 1965-1975}

Trong các năm từ 1965-1975 (hình 4d) ở ven biển Hải Hậu - Giao Thủy phải hứng chịu nhiều trận bão lớn. Mưa lũ đã có tác động mạnh tới vùng ven biển ĐBSH nói chung trong đó có khu vực ven biển tỉnh Nam Định. Trong giai đoạn này, bờ biển Hải Hậu - Giao Thủy phát triển thiên về trạng thái xói lở. Vùng bờ xói lở kéo dài gần $23 \mathrm{~km}$, từ thị trấn Quất Lâm (Giao Thủy) đến khu vực xã Hải Hòa (Hải Hậu). Vùng bờ xói lở rộng nhất tới 900m và trung bình là $150 \mathrm{~m}$, tương đương tốc độ xói trung bình $15 \mathrm{~m} /$ năm và lớn nhất là $90 \mathrm{~m} /$ năm. Bên cạnh các đoạn bờ xói lở, quá trình bồi tụ diễn ra xen kẽ trên các đoạn ngắn trên địa phận huyện Hải Hậu và Giao Thủy. Vùng bồi tụ chính diễn ra trên đoạn bờ biển thị trấn Thịnh Long (Hải Hậu); doi cát tại Thịnh Long kéo dài thêm $1,5 \mathrm{~km}$ về hướng Nam Tây Nam, tương đương tốc độ kéo dài doi cát trung bình $150 \mathrm{~m} /$ năm. 
Tạp chí Các Khoa học về Trái Đất, 38 (1), 118-130

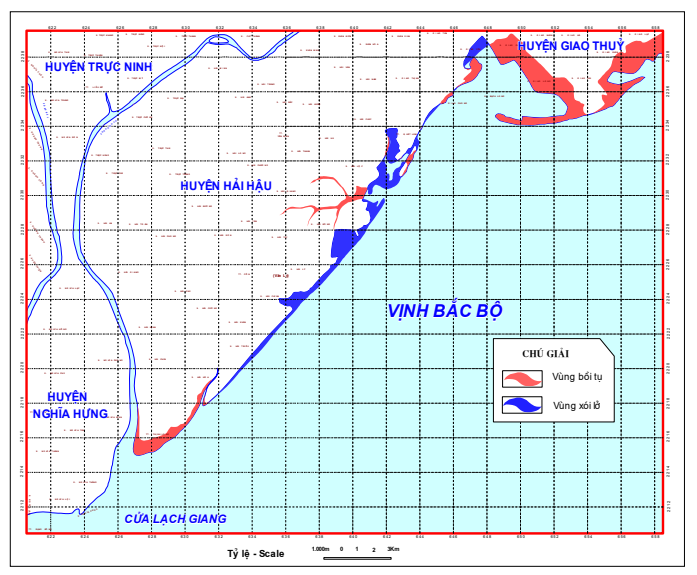

(a) $1912-1935$

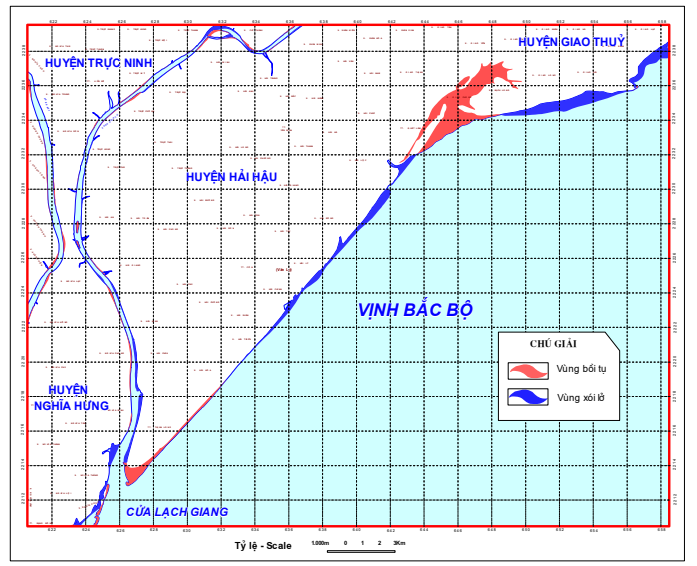

(c) $1953-1965$

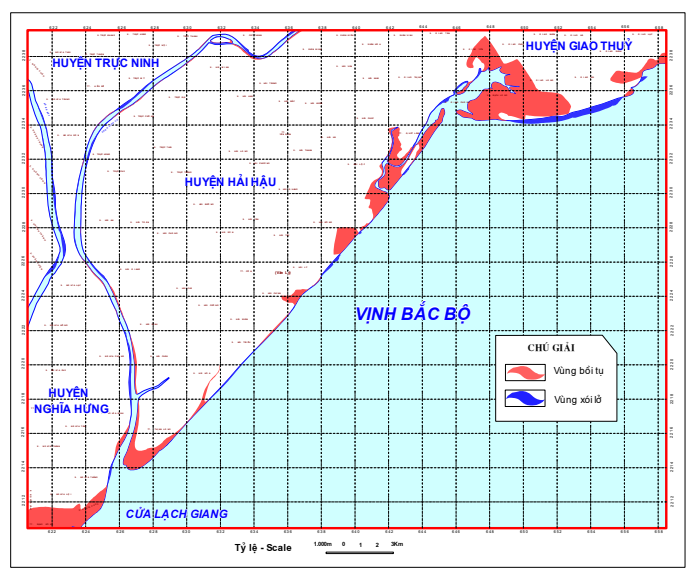

(b) $1935-1953$

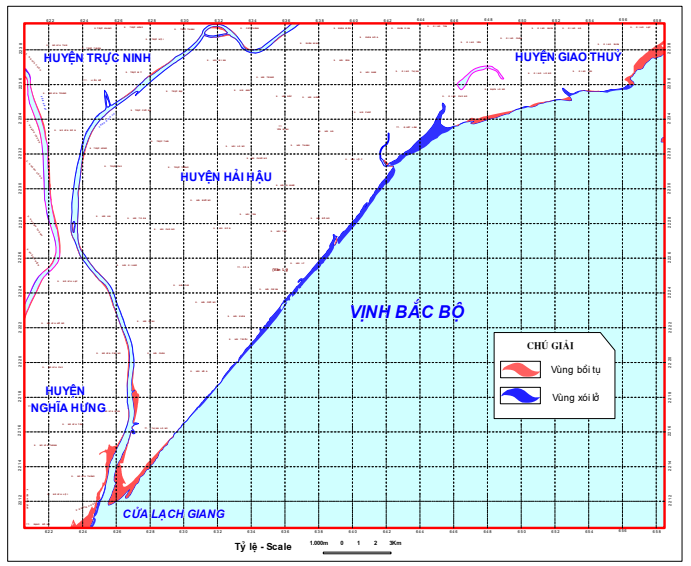

(d) $1965-1975$

Hình 4. Diễn biến xói lở - bồi tụ ven biển Hải Hậu và lân cận, trong các giai đoạn từ 1912 đến 1975

\subsubsection{Giai đoan năm 1975-1989}

Tương tự như giai đoạn trước, các năm từ 1975-1990 (hình 5a) ven biển Hải Hậu - Giao Thủy nằm trong thời kỳ xói lở mạnh. Đoạn bờ xói lở thuộc ven biển huyện Giao Thủy có chiều dài hơn $11 \mathrm{~km}$, kéo dài từ xã Giao Lạc đến xã Bạch Long. Đoạn bờ xói lở thuộc địa phận Hải Hậu có chiều dài tới $22,5 \mathrm{~km}$, kéo dài từ xã Hải Đông đến thị trấn Thịnh Long. Vùng bờ xói lở rộng nhất tới $450 \mathrm{~m}$ và trung bình rộng $135 \mathrm{~m}$, tương đương tốc độ xói lở trung bình là $9 \mathrm{~m} /$ năm và lớn nhất đạt tới $30 \mathrm{~m} /$ năm . Vùng bờ bồi tụ nhẹ diễn ra ở doi cát cửa sông thuộc khu vực cửa Lạch Giang (thị trấn Thịnh Long) và lạch nước nông thuộc xã Giao Phong (h. Giao Thủy).

\subsubsection{Giai đoạn năm 1989-1995}

Trong các năm từ 1989-1995 (hình 5b) ven biển Hải Hậu - Giao Thủy diễn ra bồi tụ và xói lở xen kẽ, nhưng thiên về trạng thái xói lở. Vùng xói lở mạnh nhất diễn ra trên đoạn bờ các xã Hải Đông và Hải Lý (Văn Lý). Các đoạn bờ xói mạnh có chiều dài từ $2,2 \mathrm{~km}$ đến $2,8 \mathrm{~km}$. Chiều rộng trung bình vùng xói từ $150 \mathrm{~m}$ đến $180 \mathrm{~m}$, lớn nhất tới 480m; tương ứng với tốc độ xói lở trung bình 30 $36 \mathrm{~m} / \mathrm{năm}$ và mạnh nhất tới $95 \mathrm{~m} /$ năm. Đoạn bờ bồi tụ mạnh nằm trên địa phận $\mathrm{TT}$. Quất Lầm và xã Giao Phong (h. Giao Thủy). Vùng bờ bồi tụ kéo dài $4,2 \mathrm{~km}$. Vùng bồi có chiều rộng trung bình $90 \mathrm{~m}$ và lớn nhất $250 \mathrm{~m}$; tương đương tốc độ bồi tụ trung bình là $18 \mathrm{~m} /$ năm và lớn nhất đạt $50 \mathrm{~m} /$ năm. Đoạn bờ biển Hải Hậu từ xã Hải Triều đến TT. Thịnh 


\section{P.Q. Sơn và N.Đ. Anh/Tạp chí Các Khoa học về Trái Đất, Tập 38 (2016)}

Long được bồi tụ nhẹ; doi cát dọc cửa Lạch Giang thuộc TT. Thịnh Long tiếp tục bị xói lở mạnh về

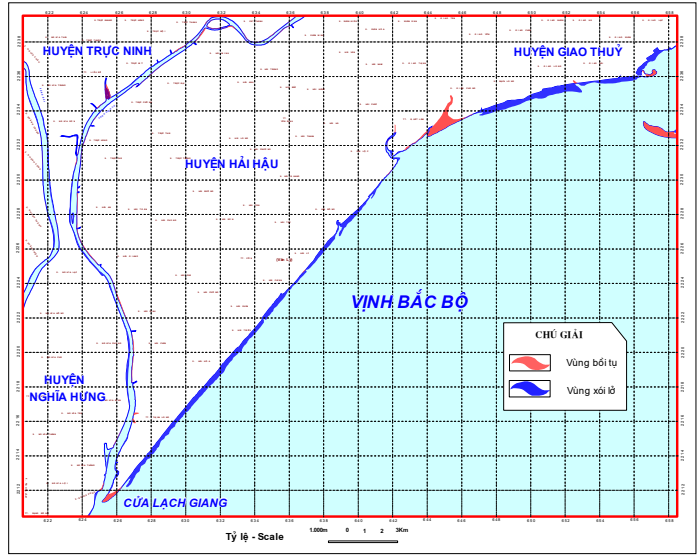

(a) $1975-1989$



(c) 1995-2001 phía sông Ninh Cơ, nhưng lại được bồi tụ nhẹ ở phía biển.

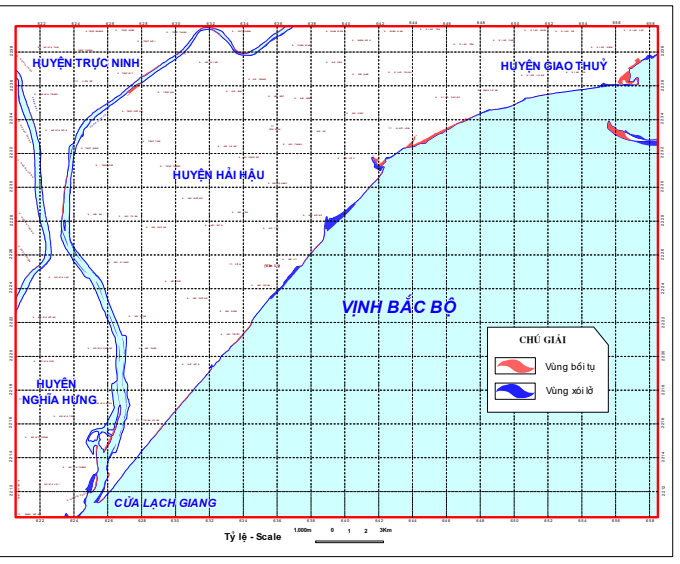

(b) 1989-1995

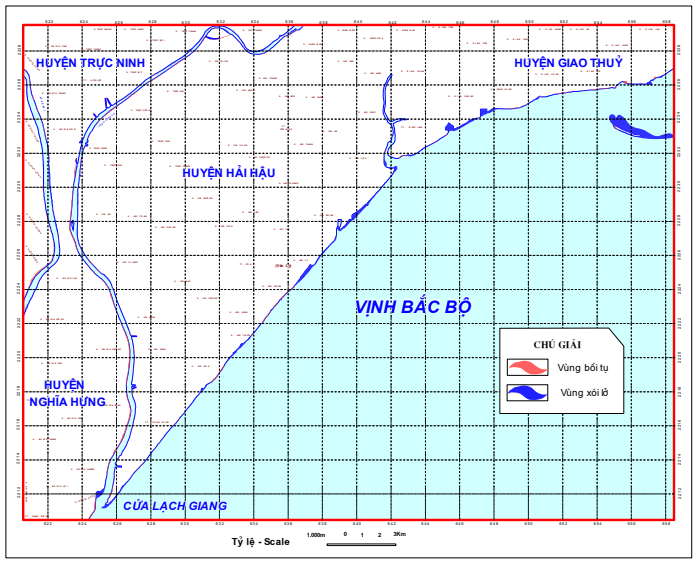

(d) 2001-2005

Hình 5. Diễn biến xói lở - bồi tụ ven biển Hải Hậu và lân cận, trong các giai đoạn từ 1975 đến 2005

\subsubsection{Giai đoạn năm 1995-2001}

Các năm từ 1995 đến 2001 (hình 5c) ven biển các huyện Hải Hậu và Giao Thủy phát triển trong tình trạng xói - bồi diễn ra xen kẽ và thiên về trạng thái xói lở. Vùng bờ xói lở ở ven biển Hải Hậu kéo dài gần $15 \mathrm{~km}$ từ xã Hải Triều tới TT. Thịnh Long. Chiều rộng vùng xói trung bình là $55 \mathrm{~m}$, lớn nhất là $130 \mathrm{~m}$, tương đương tốc độ xói lở trung bình $9 \mathrm{~m} /$ năm và lớn nhất là $22 \mathrm{~m} /$ năm . Vùng bờ xói lở thuộc h.Giao Thủy kéo dài $4,5 \mathrm{~km}$, từ $\mathrm{TT}$. Quất Lâm tới địa phận xã Bạch Long. Chiều rộng trung bình vùng xói là $95 \mathrm{~m}$, rộng nhất là $190 \mathrm{~m}$, tương đương tốc độ xói trung bình $16 \mathrm{~m} /$ năm và lớn nhất là $32 \mathrm{~m} /$ năm.

Các vùng bồi tụ chủ yếu diễn ra trên đoạn TT. Quất Lâm đến Văn Lý, trên các đoạn ngắn. Vùng bồi tụ có chiều dài từ $1,3 \mathrm{~km}$ đến $3,4 \mathrm{~km}$. Chiều rộng vùng bồi từ $150 \mathrm{~m}$ đến $260 \mathrm{~m}$ và rộng nhất $470 \mathrm{~m}$, tương đương tốc độ bồi trung bình là $25 \mathrm{~m} /$ năm và lớn nhất $95 \mathrm{~m} /$ năm. Doi cát dọc cửa Lạch Giang (địa phận TT. Thịnh Long) được bồi tụ nhẹ, phát triển kéo dài về phía Tây Nam, dài thêm $350 \mathrm{~m}$. 
Tạp chí Các Khoa học về Trái Đất, 38 (1), 118-130

\subsubsection{Giai đoạn năm 2001-2005}

Trong các năm từ 2001-2005 (hình 5d) ở ven biển các huyện Hải Hậu - Giao Thủy phát triển theo trạng thái xói lở - bồi tụ diễn ra xen kẽ trên các đoạn ngắn, nhưng thiên về xói lở. Vùng xói lở chính xuất hiện trên các đoạn bờ Giao Phong Bạch Long (Giao Thủy) với chiều dài vùng xói là $3,2 \mathrm{~km}$. Ở khu vực các xã Hải Đông - Hải Lý (Hải Hậu) đoạn bờ xói lở có chiều dài tới $9,1 \mathrm{~km}$; chiều rộng vùng bờ xói từ $50 \mathrm{~m}$ đến $120 \mathrm{~m}$, lớn nhất tới $320 \mathrm{~m}$, tương đương tốc độ xói trung bình từ $12 \mathrm{~m}$

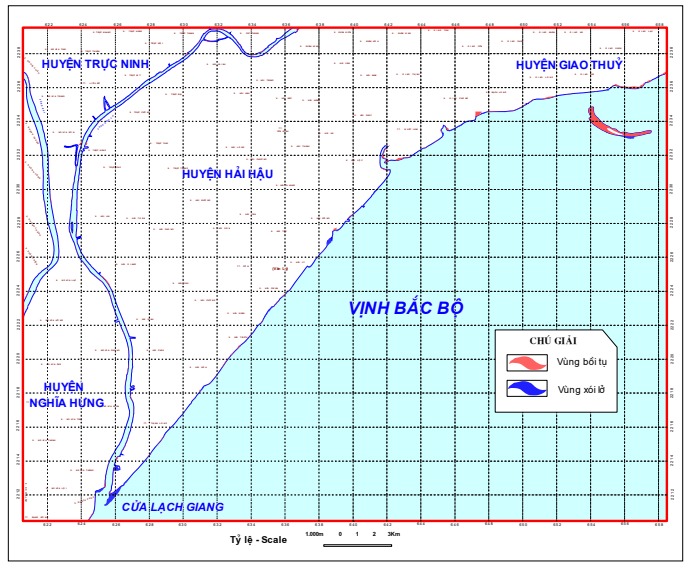

(a) 2005-2010 đến $30 \mathrm{~m} /$ năm và lớn nhất tới $80 \mathrm{~m} /$ năm. Doi cát nằm kề cửa Lạch Giang (thuộc địa phận TT. Thịnh Long) bị xói lở mạnh, chiều dài vùng xói lở tới $1,9 \mathrm{~km}$.

Tính chung, trong giai đoạn này ven biển các huyện Hải Hậu - Giao Thủy bờ biển bị xói lở mạnh, do hứng chịu tác động của những trận bão mạnh. Điển hình là trận bão đổ bộ vào Nam Định ngày 23/09/2005 đã làm một số đoạn đê biển ở Hải Hậu - Giao Thủy bị vỡ, gây ngập lụt nặng nề cho các xã ven biển.

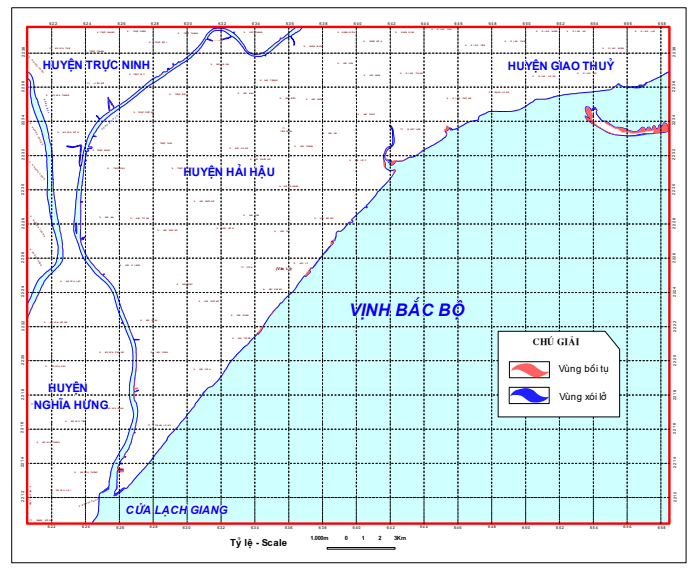

(b) 2010-2014

Hình 6. Diễn biến xói lở - bồi tụ ven biển Hải Hậu và lân cận, trong các giai đoạn từ 2005 đến 2014

\subsubsection{Giai đoạn năm 2005-2010}

Trong các năm từ 2005 đến 2010 (hình 6a) ven biển Hải Hậu - Giao Thủy đường bờ biển tương đối ổn định. Các đoạn bồi tụ nhẹ và xói lở với quy mô không lớn diễn ra xen kẽ nhau trên các đoạn ngắn, kéo dài từ 1,5 đến $4,2 \mathrm{~km}$. Khu vực xói lở mạnh nhất là doi cát nằm kề cửa Lạch Giang (địa phận TT. Thịnh Long) đã bị xói lở mạnh. Đoạn doi cát bị xói lở này có chiều dài $2,2 \mathrm{~km}$; chiều rộng trung bình vùng xói là $140 \mathrm{~m}$ và lớn nhất là $320 \mathrm{~m}$; tương đương tốc độ xói trung bình là $28 \mathrm{~m} /$ năm và lớn nhất tới $64 \mathrm{~m} /$ năm. Sự biến mất dần của doi cát nằm kề cửa Lạch Giang, chứng tỏ trục lòng dẫn chính ở cửa sông Ninh Cơ biến động mạnh; hướng trục lòng dẫn chuyển dịch dần từ hướng Nam Tây Nam về hướng Nam.

\subsubsection{Giai đoạn năm 2010-2014}

Trong các năm từ 2010 đến 2014 (hình 6b) ở ven biển các huyện Hải Hậu - Giao Thủy bờ biển phát triển và biến động với tốc độ không lớn. Các đoạn bờ được bồi tụ và xói lở diễn ra xen kẽ nhau trên từng đoạn ngắn. Khu vực có biến động chính nằm giữa các xã Hải Lý và Hải Triều, với một số đoạn bồi tụ và xói lở cục bộ. Đáng lưu ý là doi cát nằm kề cửa Lạch Giang (địa phận $\mathrm{TT}$. Thịnh Long) tiếp tục bị xói lở mạnh. Đoạn doi cát bị xói lở mạnh có chiều dài tới $850 \mathrm{~m}$, vùng xói rộng trung bình $115 \mathrm{~m}$, tương đương tốc độ xói lở $38 \mathrm{~m} /$ năm. Đến cuối năm 2014 đầu 2015, doi cát này đã bị xói lở hoàn toàn (hình 7 ).

Tại cửa Lạch Giang ngành Giao thông đã triển khai một dự án lớn với sự trợ giúp của các chuyên gia tư vấn Pháp, xây dựng luồng giao thông thủy mới đi qua cửa sông Ninh Cơ, cho tầu thuyền vào các cảng nội địa khu vực phía nam ĐBSH. Tuyến luồng mới mở cắt qua vị trí doi cát phía TT. Thịnh Long; luồng tầu có chiều rộng $300 \mathrm{~m}$, trục chính tuyến luồng theo hướng Tây Bắc - Đông Nam 


\section{P.Q. Sơn và N.Đ. Anh/Tạp chí Các Khoa học về Trái Đất, Tập 38 (2016)}

(hình 7). Dọc theo tuyến luồng mới là công trình kỹ thuật gồm các đê ngăn cát, giảm sóng đảm bảo độ an toàn và ổn định cho luồng tầu. Dự án luồng mới hoàn thành có thể cho tầu biển trọng tải 3.000 tấn ra vào sông Ninh Cơ và tháng 12/2015 luồng tàu này đã được đưa vào khai thác.

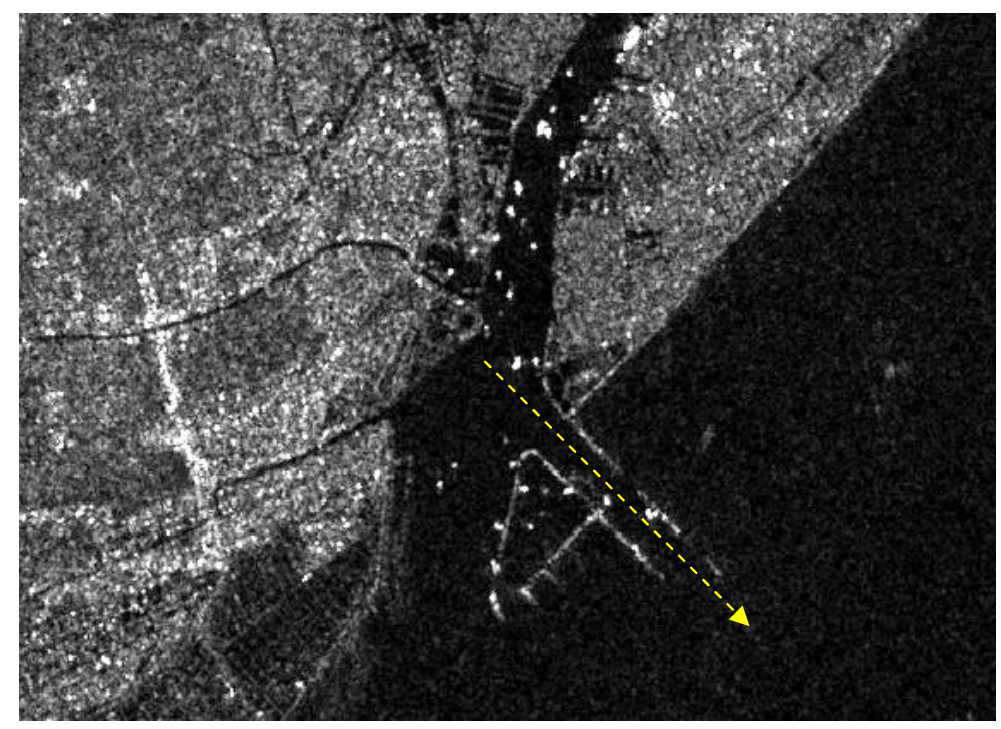

(------>, Hướng đi của tuyến luồng)

Hình 7. Luồng tàu mới khi được xây dựng tại cửa Lạch Giang (s. Ninh Cơ), (ảnh SAR, vệ tinh Sentinel-1, chụp tháng 1/2015)

\subsection{Kết quả khảo sát thục địa kiểm tra ở ven biển Hải Hậu và lân cận}

Các đợt khảo sát thực địa tiến hành vào tháng $9 / 2000$, tháng $8 / 2005$, tháng $5 / 2011$ và tháng 8/2012 nhằm kiểm tra các kết quả xử lý ảnh vệ tinh. Các biến động mạnh mẽ ở ven biển Hải Hậu và lân cận ghi nhận được qua khảo sát thực địa cho thấy vùng nghiên cứu đang bị tác động mạnh không những bởi các nhân tố tự nhiên (do sóng gió, thủy triều, dòng chảy ven biển, dòng bùn cát...) mà còn có các hoạt động khai thác và chỉnh trị, như chặt phá rừng ngập mặn (RNM), đào kênh dẫn nước, khoanh ô nuôi trồng thủy sản, xây dựng hệ thống kè hộ đê ven biển,...

Kết quả khảo sát thực địa còn cho thấy những phương thức chuyển đổi sử dụng đất ven biển Nam Định diễn ra mạnh mẽ khi có những thay đổi về chính sách kinh tế của Nhà nước. Các hoạt động khai thác ven biển diễn ra ngày càng mạnh mẽ hơn, luôn có tác động hai mặt tới quá trình phát triển tự nhiên ở khu vực này. Việc chặt phá RNM để làm các đầm nuôi tôm và các ô nuôi thủy sản nước lợ vào đầu những năm 1990 diễn ra một cách ồ ạt, thiếu tổ chức đã để lại những tác động xấu đến môi trường. Sau năm 1995, việc tái trồng RNM ở ven biển đã có tác động tích cực, hạn chế xói lở vùng đất mới bồi ở cửa sông. Hiện tượng bồi tụ trở lại sau nhiều năm diễn ra xói lở cục bộ ở khu vực cửa $\mathrm{Ba}$ Lạt và cửa Đáy, cửa Lạch Giang còn có một nguyên nhân khác là trong thời gian khoảng 20 năm gần đây không có lũ lớn, bão và ATNĐ ít đổ bộ trực tiếp vào ven biển ĐBSH nói chung, ven biển Nam Định nói riêng (trừ trường hợp bão trong các năm 1996, 2005, 2012).

\section{3. Đánh giá chung về diễn biến xói lở - bồi tụ ven biển Hải Hậu và lân cận trong hơn 100 năm qua}

Bờ biển Hải Hậu và lân cận trong khoảng 100 năm qua (1912-2014) diễn ra quá trình biến động rất mạnh, thiên về trạng thái xói lở, do tác động của các nhân tố tự nhiên cũng như hoạt động khai thác, chỉnh trị ven biển. Những thời kỳ bờ biển biến động mạnh nhất do tác động của bão, áp thấp kèm theo tác động trực tiếp của sóng biển và dòng chảy ven bờ. Kết cấu các thành tạo địa chất ven biển là các vật liệu bở rời (cát nhỏ, cát bột, bùn bột, sét,...) nên dễ bị tác động phá hủy do sóng và 
Tạp chí Các Khoa học về Trái Đất, 38 (1), 118-130

dòng chảy ven bờ. Hệ thống đê-kè chắn sóng ven biển đã có tác dụng làm giảm tốc độ xói lở bờ (Nguyễn Văn Hạnh, 2015; Phạm Quang Sơn và nnk, 2007; Trần Đức Thạnh, 2008). Kết quả là đường bờ biển hiện nay đã lùi đến chân đê và kè biển; tạo thành đoạn bờ biển dài hàng chục $\mathrm{km}$ có hình thái khá thẳng theo hướng $\mathrm{ĐB}-\mathrm{TN}$ và hầu như không còn bãi triều dưới chân đê - kè biển. Một số khu dân cư trước đây đã bị nhấn chìm trong nước biển. Cũng cần nhấn mạnh, địa hình ven biển Hải Hậu và lân cận khá thấp, nên nguy cơ bị chìm ngập cao khi các tuyến đê ngăn nước biển và ngăn lũ không còn tác dụng. Qua phân tích các tài liệu ảnh vệ tinh, bản đồ, kết quả khảo sát thực địa,... cho thấy quy mô biến động ven biển Hải Hậu và lân cận diễn ra không như nhau (hình 8 , bảng 1 ).

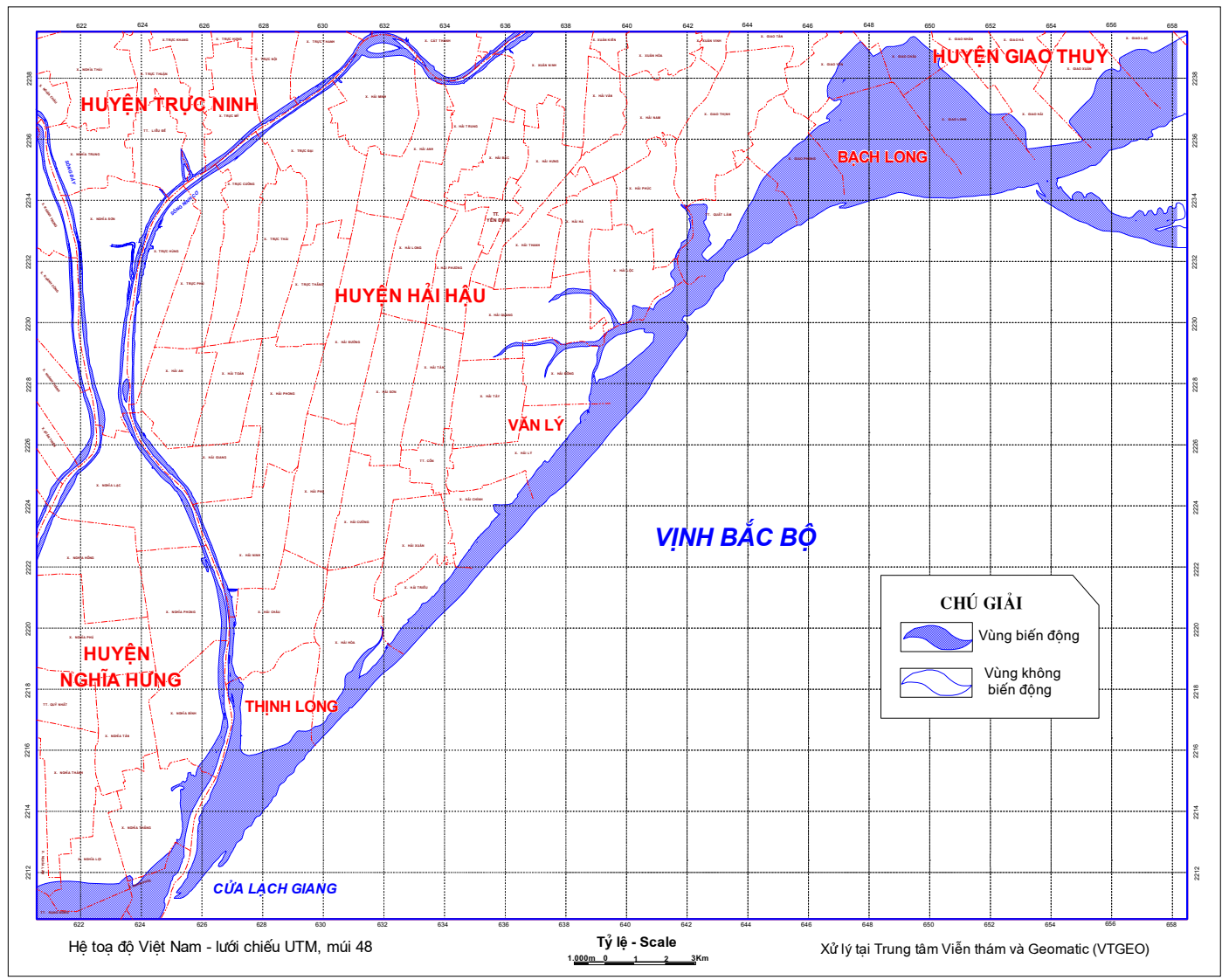

Hình 8. Phân bố không gian và quy mô biến động ven biển Hải Hậu và lân cận, trong thời gian từ năm 1912 đến 2014

Dựa vào quy mô và đặc điểm phát triển riêng, có thể chia đoạn bờ nghiên cứu làm $3 \mathrm{khu}$ vực, với tính chất mỗi khu vực như sau:

- Đoạn bờ bồi tụ - xói lở diễn ra xen kẽ và thiên về trạng thái bồi tụ, là khu vực các xã Giao Long Bạch Long (h. Giao Thủy). Phương thức bồi tụ nhân tạo chủ yếu do quai đê lấn biển, đã diễn ra mạnh mẽ trong những năm 1960-1980; vùng bồi tụ có chiều rộng lớn nhất tới $5.300 \mathrm{~m}$.
- Đoạn bờ xói lở chính thuộc ven biển huyện Hải Hậu, có chiều dài $23,5 \mathrm{~km}$, từ xã Hải Đông đến xã Hải Hòa. Đoạn bờ biển bị xói lở mạnh nhất thuộc khu vực Văn Lý (xã Hải Lý), có chiều rộng vùng xói lớn nhất tới $1.350 \mathrm{~m}$. Hiện tượng xói lở ở đây đã diễn ra liên tục trong khoảng 100 năm qua.

- Đoạn bờ bồi tụ - xói lở với cường độ trung bình, thuộc ven biển thị trấn Thịnh Long (Hải hậu). Khu vực này, doi cát ven cửa sông Ninh Cơ phát triển kéo dài trong khoảng 90 năm (1912- 


\section{P.Q. Sơn và N.Đ. Anh/Tạp chí Các Khoa học về Trái Đất, Tập 38 (2016)}

2005), sau đó bị xói lở mạnh trong những năm gần đây (2005-2014). Hiện nay ở doi cát cửa Lạch Giang, ngành Giao thông đã xây dựng tuyến luồng đường thủy mới đi vào sông Ninh Cơ và tầu thuyền có thể đi đến các cảng thủy nội địa khu vực phía nam ĐBSH.

Bảng 1. Tổng hợp diễn biến xói lở - bồi tụ ven biển Hải Hậu trong thời gian 1912-2014; Ghi chú: (+) tình trạng bồi tụ; (-) tình trạng xói lở; (+/-) tình trạng bồi - xói xen kẽ

\begin{tabular}{|c|c|c|c|c|}
\hline \multirow[b]{2}{*}{ Giai đoạn } & \multicolumn{4}{|c|}{ Diễn biến xói lở - bồi tụ } \\
\hline & $\begin{array}{l}\text { Khu vực bờ biển } \\
\text { Giao Long - Bạch } \\
\text { Long (Giao Thủy) }\end{array}$ & $\begin{array}{c}\text { Khu vực bờ biển } \\
\text { Hải Đông - Hải Hòa } \\
\text { (Hải Hậu) }\end{array}$ & $\begin{array}{c}\text { Khu vực } \\
\text { bờ biển Thịnh Long } \\
\text { (Hải Hậu) }\end{array}$ & $\begin{array}{c}\text { Đánh giá tình trạng bờ biển Hải Hậu } \\
\text { và lân cận }\end{array}$ \\
\hline $1912-1935$ & $(+)$ & $(-)$ & $(+)$ & Bờ biển xói lở mạnh, cửa sông được bồi tụ nhẹ \\
\hline $1935-1953$ & $(+/-)$ & $(+)$ & $(+)$ & $\begin{array}{l}\text { Bờ biển và các cửa sông ở trạng thái thiên về } \\
\text { bồi tụ }\end{array}$ \\
\hline $1953-1965$ & $(+/-)$ & $(-)$ & $(+)$ & Bờ biển xói lở mạnh, các cửa sông bồi tụ nhẹ \\
\hline $1965-1975$ & $(-)$ & $(-)$ & $(+)$ & Bờ biển xói lở mạnh, cửa sông bồi tụ trung bình \\
\hline $1975-1989$ & $(-)$ & $(-)$ & $(+/-)$ & $\begin{array}{l}\text { Bờ biển ở trạng thái xói lở, các cửa sông ít ổn } \\
\text { định, }\end{array}$ \\
\hline 1989-1995 & $(+)$ & $(-)$ & $(-)$ & $\begin{array}{l}\text { Bờ biển Hải Hậu xói lở, bờ biển Giao Thủy bồi } \\
\text { tụ nhẹ }\end{array}$ \\
\hline $1995-2001$ & $(+/-)$ & $(+/-)$ & $(+/-)$ & $\begin{array}{l}\text { Bờ biển và các cửa sông ít ổn định, xói - bồi } \\
\text { xen kẽ }\end{array}$ \\
\hline 2001-2005 & $(-)$ & $(-)$ & $(-)$ & Bờ biển và các cửa sông xói lở mạnh \\
\hline $2005-2010$ & $(+)$ & $(+/-)$ & $(-)$ & $\begin{array}{l}\text { Bờ biển Hải Hậu ít ổn định, thiên về trạng thái } \\
\text { xói lở }\end{array}$ \\
\hline $2010-2014$ & $(+/-)$ & $(+/-)$ & $(-)$ & $\begin{array}{l}\text { Bờ biển Hải Hậu ít ổn định, thiên về trạng thái } \\
\text { xói nhẹ }\end{array}$ \\
\hline Nhận xét & $\begin{array}{l}\text { Bồi - xói diễn ra xen } \\
\text { kẽ, thiên về trạng thái } \\
\text { bồi tụ }\end{array}$ & $\begin{array}{l}\text { Bờ biển bị xói lở } \\
\text { mạnh, không ổn định }\end{array}$ & $\begin{array}{l}\text { Bồi - xói diễn ra xen } \\
\text { kẽ, cửa sông ít ổn } \\
\text { định }\end{array}$ & $\begin{array}{l}\text { Bờ biển Hải Hậu và vùng lân cận có diễn biến } \\
\text { xói-bồi khá phức tạp, bờ biển không ổn định }\end{array}$ \\
\hline
\end{tabular}

\section{Kết luận}

Hơn 100 năm qua, ven biển Hải Hậu và vùng lân cận có diễn biến khá phức tạp; bên cạnh khu vực cửa sông được bồi tụ mạnh, thì bờ biển Hải Hậu là vùng xói lở rất điển hình về cả quy mô không gian và thời gian. Những biến động ở ven biển Hải Hậu diễn ra liên tục dưới tác động của nhiều nhân tố khác nhau. Qua phân tích kết quả nghiên cứu cho thấy:

- Hiện tượng xói lở bờ biển đã diễn ra liên tục trên đoạn bờ huyện Hải Hậu từ địa phận xã Hải Đông đến Hải Hoà. Vùng xói nghiêm trọng nhất thuộc địa phận các xã Hải Đông, Hải Lý, Hải Chính, Hải Triều. Hiện tượng xói lở bờ biển diễn ra mạnh mẽ vào các thời kỳ có bão và $\mathrm{ATNĐ} \mathrm{tác}$ động mạnh, có tần suất xuất hiện cao .

- Trong khoảng 20 năm trở lại đây tần suất hoạt động của bão và ATNĐ ở ven biển ĐBSH thấp hơn trung bình nhiều năm; hiện tượng xói lở bờ biển và tốc độ biến động vùng ven biển Hải Hậu có giảm so với những giai đoạn trước.

- Tuyến đê biển ở Hải Hậu và lân cận thường xuyên được củng cố, nâng cấp đã góp phần giảm thiểu không gian vùng bờ xói lở. Tuy vậy, do phần lớn bãi triều ở chân đê biển đã bị xói lở, nên khả năng sóng biển tác động trực tiếp vào tuyến đê rất cao, gây tác động xấu đến dân cư và các công trình ven biển.

- Trong bối cảnh biến đổi khí hậu và nước biển dâng, thì yêu cầu về nghiên cứu chỉnh trị, nhằm đưa ra những giải pháp hữu hiệu để bảo vệ tuyến đê biển cũng như các khu dân cư quan trọng ở ven biển Hải Hậu là rất cấp thiết.

- Những kết quả trình bày trong khuôn khổ bài báo này dựa trên phân tích, đánh giá các tài liệu bản đồ địa hình và tư liệu viễn thám đa thời gian. Trong nội dung bài báo không đi sâu đánh giá về các nhân tố động lực chính gây ra biến động bờ biển Hải Hậu - thông qua hai quá trình trái ngược nhau là xói lở và bồi tụ. 
Tạp chí Các Khoa học về Trái Đất, 38 (1), 118-130

\section{Tài liệu dẫn}

Lương Tuấn Anh (chủ biên), 2013: Nghiên cứu tác động của việc sử dụng nước phía thượng lưu đến tài nguyên nước lưu vực sông Hồng. Báo cáo đề tài cấp Bộ TNMT, Viện Khoa học Khí tượng-Thủy văn và Môi trường, Hà Nội2013. 169tr.

Nguyễn Văn Cư và nnk, 1990: Động lực vùng ven biển cửa sông Việt Nam. Phần nghiên cứu cửa sông. Báo cáo đề tài 48B-02-01. Chương trình nghiên cứu biển 48B-02 (19861990), Viện KHVN. Hà Nội-1991, 355tr.

Nguyễn Địch Dỹ và nnk, 2009: Nghiên cứu biến động cửa sông và môi trường trầm tích Holocen - hiện đại vùng ven bờ châu thổ sông Cửu Long, phục vụ phát triển bền vững kinh tế-xã hội. Báo cáo tổng kết đề tài KC.09.06/06-10. Bộ Khoa học và Công nghệ, Hà Nội.

Gérard Maire et Pham Quang Son, 1993: Aspects structureles de la dynamique fluviale du Fleuve Rouge (Song Hong) entre Son Tay et Ha Noi. L'Eau, la Terre et les Hommes. Presses Universitaires de Nancy, pp 329-336.

Giles Foody \& Paul Curran, 1994: Environmental Remote Sensing from Regional to Global scales. John Wiley \& Sons Ltd. England.

Nguyễn Văn Hạnh, 2015. Đề xuất một số giải pháp ổn định bờ biển Nam Định. Hội thảo khoa học đề tài "Nghiên cứu, đánh giá và đề xuất một số giải pháp ổn định bờ biển Nam Định”. Sở KHCN tỉnh Nam Định, tháng 5/2015.

Michel GIRARD et autre, 1989: Télédétection appliquée. Zones tempérées et intertropicale. Masson. Paris -1989. 260pp.

Vũ Thị Thu Lan (chủ biên), 2015: Nghiên cứu đánh giá tác động của hạn kinh tế-xã hội đến hạ du sông Hồng và đề xuất các giải pháp ứng phó. Tóm tắt báo cáo đề tài cấp nhà nước KC08.10/11-15. Viện Địa lý, Viện HLKH\&CNVN, Hà Nội, 38tr.

Doãn Đình Lâm, 2002: Lịch sử tiến hoá trầm tích Holocen châu thổ sông Hồng. Luận án tiến sỹ Địa chất. Trường Đại học Khoa học Tự nhiên, ĐHQG Hà Nội, 152tr.

Vũ Văn Phái, Nguyễn Hoàn, Nguyễn Hiệu, 2002: Tiến hóa địa mạo vùng cửa sông $B a$ Lạt trong thời gian gần đây. Tạp chí Khoa học, ĐH Quốc gia Hà Nội. Số 2 (T.XVIII)/2002. Hà Nội, tr.44-53.

Trần Nghi và nnk, 2000: Tiến hoá trầm tích Kainozoi bồn trũng sông Hồng trong mối quan hệ với hoạt động kiến tạo. Tạp chí Các Khoa học về Trái Đất, T.22, 4, tr.290-305.

Phạm Quang Sơn, 2004: Diễn biến lòng dẫn hạ lưu sông Hồng trong 15 năm vận hành khai thác nhà máy thủy điện Hòa Bình. Tc. Các Khoa học về Trái Đất, T.26, 4, tr.520-531.

Phạm Quang Sơn và nnk, 2007: Diễn biến vùng ven biển các tỉnh Nam Định, Ninh Bình trước và sau khi có công trình thủy điện Hoà Bình qua phân tích thông tin viễn thám và GIS. Tc. Các Khoa học về Trái Đất, T.29, 3, tr.267-276. .

Phạm Quang Sơn và nnk, 2011: Diễn biến vùng cửa sông ven biển Hải Phòng và những vấn đề khai thác trong bối cảnh biến đổi khí hậu và nước biển dâng. Hội nghị KHCN Biển toàn quốc lần thứ 5 . Phần báo cáo Địa lý - Địa chất và Địa vật lý biển. Quyển 3, tr.556-568.

Trần Đức Thạnh, 2008: Tác động của sóng, bão đối với các công trình bờ biển Bắc Bộ và giải pháp phòng tránh. Tc. Các Khoa học về Trái Đất, T.30, 4, tr.555-565. 